\title{
Effect of Helicobacter pylori and its eradication on gastric juice ascorbic acid
}

\author{
S Banerjee, C Hawksby, S Miller, S Dahill, A D Beattie, K E L McColl
}

\begin{abstract}
The presence of ascorbic acid in gastric juice may protect against gastric carcinoma and peptic ulceration. This study examined the effect of Helicobacter pylori (H pylori) on the secretion of ascorbic acid into gastric juice by measuring fasting plasma and gastric juice ascorbic acid concentrations in patients with and without the infection and also before and after its eradication. Gastric juice ascorbic acid concentrations in $19 \mathrm{H}$ pylori positive patients were significantly lower (median $2 \cdot 8$, range $0-28.8 \mu \mathrm{g} / \mathrm{ml}$ ) than those in $10 \mathrm{H}$ pylori negative controls (median $17 \cdot 8$, range $5 \cdot 6$ $155.4 \mu \mathrm{g} / \mathrm{ml}) \quad(\mathrm{p}<0.0005)$ despite similar plasma ascorbic acid concentrations in both groups. The median gastric juice:plasma ascorbic acid ratio in the $H$ pylori positive patients was only 1.16 (range $0.02-6 \cdot 67$ ), compared with a median ratio of 4.87 (range 0.76$21.33)$ in $H$ pylori negative controls $(p<0.01)$. In the patients with $H$ pylori infection there was a significant negative correlation between the severity of the antral polymorphonuclear infiltrate and gastric juice ascorbic acid concentrations (correlation coefficient $\mathbf{- 0 . 5 2}$, $\mathrm{p}=0.02$ ). After eradication of $\boldsymbol{H}$ pylori in 11 patients, gastric juice ascorbic acid concentrations rose from $2.4(0-12.8 \mu \mathrm{g} / \mathrm{ml})$ to $11.2(0-50$ $\mu \mathrm{g} / \mathrm{ml})(p=0.01)$. The median gastric juice: plasma ascorbic acid ratio also increased from $1.33(0.05-6.67)$ to $2.89(0.01-166)(p=0.01)$. In conclusion, the high gastric juice:plasma ascorbic acid ratio in $\boldsymbol{H}$ pylori negative subjects shows active secretion of ascorbic acid into gastric juice. Secondly, $H$ pylori infection causes a reversible lowering of gastric juice ascorbic acid concentrations, which may predispose to gastric carcinoma and peptic ulceration.
\end{abstract}

(Gut 1994; 35: 317-322)

Gastrointestinal Centre, Southern General Hospital, Glasgow $S$ Baneriee

A D Beattie

Department of Medicine and Therapeutics, Western Infirmary, Glasgow

C Hawksby

$S$ Miller

$S$ Dahill

K E L McColl

Correspondence to:

Dr K E L McColl, University Department of Medicine and Therapeutics, Western Infirmary, Glasgow G11 6NT. Accepted for publication 26 July 1993
Ascorbic acid, the reduced form of vitamin C, is present in the gastric juice of healthy subjects in concentrations considerably higher than those in plasma. ${ }^{1-4}$ This high gastric juice:plasma ascorbic acid ratio implies active secretion of ascorbic acid by the gastric mucosa. The importance of this secretory mechanism may lie in the ability of ascorbic acid to protect against the development of gastric cancer $^{5-9}$ and possibly also against developing peptic ulceration.

In subjects with chronic gastritis, gastric juice ascorbic acid concentrations are considerably lower than those in healthy controls. ${ }^{1-4}$ The major cause of chronic gastritis is Helicobacter pylori ( $H$ pylori) infection and the change in gastric juice ascorbic acid concentrations may play a part in the association of $H$ pylori infection with both peptic ulceration ${ }^{10-12}$ and gastric carcinoma. ${ }^{13-15}$

Previous studies have failed to establish whether the low gastric juice ascorbic acid concentrations associated with $H$ pylori related gastritis are a consequence of the infection, or a predisposing cause to the infection. A solitary case report has suggested that acquisition of $H$ pylori infection may lead to a small fall in gastric juice ascorbic acid concentrations. ${ }^{16}$ The study subject, however, was atypical in that his preinfection gastric juice ascorbic acid concentrations were already very low, similar to median values for patients with chronic gastritis. ${ }^{1-4}$ It is possible that there might exist two population groups - low secretors and high secretors of ascorbic acid into gastric juice, with the former being more susceptible to infection with $H$ pylori. This possibility is supported by the finding that ascorbic acid inhibits the growth and urease activity of $H$ pylor in vitro. ${ }^{17}$ The reduced antioxidant activity of the gastric juice of low secretors would also make them more susceptible to gastric carcinoma and peptic ulceration, and therefore the link between these diseases and $H$ pylori gastritis could be indirect.

To examine more fully the relation between $H$ pylori infection and gastric juice ascorbic acid, we have studied subjects with and without the infection and also patients before and after its eradication.

\section{Patients and methods}

We studied $19 \mathrm{H}$ pylori positive patients (nine male) attending a gastrointestinal clinic for investigation of dyspepsia. Ten $H$ pylori negative subjects (seven male) were also studied, seven of these being dyspeptic patients and the others asymptomatic volunteers. None of the patients had had any previous gastrointestinal surgery, or suffered from other medical conditions. The finding of upper gastrointestinal disease other than erythematous gastritis or duodenitis at the time of initial endoscopy led to exclusion from entry into the study. As antisecretory drugs may lower gastric juice ascorbic acid concentrations by raising intragastric $\mathrm{pH},{ }^{4}$ patients taking these drugs were asked to stop treatment a minimum of four weeks before entry into the study. None of the patients were receiving any other treatment.

The $H$ pylori state of the study subjects was determined by carrying out a ${ }^{14} \mathrm{C}$ urea breath test, and in all subjects except the three asymptomatic volunteers, confirmed subsequently at endoscopy by a urease slide test (CLOtest - Delta West Pty Ltd, Australia) and microscopy of antral biopsy specimens. Patients attended for endoscopy after a 12 hour overnight fast. To 
correct for the circadian rhythm in the production of free radicals, ${ }^{18} 19$ which might affect gastric juice ascorbic acid concentrations, all patients were studied at the same time $(900 \mathrm{am})$. A $5 \mathrm{ml}$ sample of venous blood was withdrawn into a lithium heparin tube for measurement of plasma ascorbic acid. Patients then had an endoscopy under sedation with intravenous midazolam. On entering the stomach $5 \mathrm{ml}$ of fasting gastric juice was aspirated through a sterile plastic cannula inserted through the suction channel of the endoscope. After endoscopic evaluation of the upper gastrointestinal tract, two endoscopic biopsy specimens for histopathological examination were obtained $10 \mathrm{~cm}$ distal to the cardia from the anterior and posterior walls of the gastric corpus, and two further specimens were taken from the anterior and posterior walls of the antrum, $2 \mathrm{~cm}$ proximal to the pylorus. A further antral biopsy specimen was obtained for a CLO test. The three $H$ pylori negative asymptomatic volunteers did not have endoscopy, fasting gastric juice being collected by aspiration by a nasogastric tube.

Eradication of $H$ pylori was attempted in 13 of the $H$ pylori positive patients using triple therapy (amoxycillin $500 \mathrm{mg}$ thrice daily, tripotassium dicitratobismuthate (De-Noltab, Brocades) 240 $\mathrm{mg}$ four times daily, and metronidazole $400 \mathrm{mg}$ thrice daily, for two weeks). These patients had a repeat breath test, venesection, and endoscopy four weeks after completing their eradication therapy to check their $H$ pylori state and ascorbic acid and vitamin $C$ concentrations in plasma and gastric juice. Eight of the successfully eradicated patients were reassessed on a further occasion, four months after completion of treatment. The six $H$ pylori positive patients who did not receive eradication therapy were also reassessed six weeks later to check the reproducibility of the measurements.

\section{BIOCHEMICAL ANALYSIS}

The venous blood samples were centrifuged and a $0.5 \mathrm{ml}$ aliquot of plasma was added to $1 \mathrm{ml}$ of $2 \%$ metaphosphoric acid. The gastric juice samples were centrifuged for five minutes immediately after collection, and a $0.8 \mathrm{ml}$ aliquot of the supernatent was added to $0.8 \mathrm{ml}$ of $2 \%$ metaphosphoric acid. Both plasma and gastric juice samples were then frozen in liquid nitrogen and were subsequently transferred to a $-70^{\circ} \mathrm{C}$ freezer for storage. Analysis was carried out within seven days. The plasma and gastric juice samples were thawed, recentrifuged, and one portion of the supernatant was used to estimate ascorbic acid concentrations by high performance liquid chromatography using the methodology of Schorah et al. ${ }^{3}$ Further $0.5 \mathrm{ml}$ aliquots of the plasma and gastric juice supernatants were used to determine total vitamin $C$ concentrations. This was done by adding dithiothreitol to reduce any dehydroascorbic acid to ascorbic acid, and then using high performance liquid chromatography as above. Three mg of solid dithiothreitol was added to the $0.5 \mathrm{ml}$ aliquots of plasma and gastric juice, the samples being mixed and allowed to stand at $20^{\circ} \mathrm{C}$ for 60 minutes before refreezing at $-40^{\circ} \mathrm{C}$ for 16 hours.
The samples were then thawed once again and reanalysed. The amount of dehydroascorbic acid in the samples could be calculated by the difference between the second and first high performance liquid chromatography values for ascorbic acid for each sample. The limit of detection for the assay in our laboratory was $0 \cdot 1 \mu \mathrm{g} / \mathrm{ml}$. After correcting for dilution, the limits of detection were $0.2 \mu \mathrm{g} / \mathrm{ml}$ for gastric juice ascorbic acid, and $0.3 \mu \mathrm{g} / \mathrm{ml}$ for plasma ascorbic acid. The intra-assay coefficient of variation was $<5 \%$ and the inter-assay coefficient of variation was $<10 \%$. In the course of the study, five gastric juice samples and two plasma samples were found to have ascorbic acid concentrations below the limits of detection. In calculating the gastric juice:plasma ascorbic acid ratio for these samples, the problem of division involving the value ' 0 ' was overcome by replacing ' 0 ' with values for the limits of detection - that is, $0 \cdot 2 \mu \mathrm{g} /$ $\mathrm{ml}$ for gastric juice and $0.3 \mu \mathrm{g} / \mathrm{ml}$ for plasma.

\section{HISTOPATHOLOGICAL EXAMINATION}

The two gastric corpus and two antral biopsy specimens were fixed in formalin and were subsequently stained with haematoxylin and eosin. All specimens were reviewed by a single histopathologist and the antral and corpus gastritis scores were assessed by a previously validated method, ${ }^{20}$ final scores being expressed as the mean score of the two specimens. The polymorphonuclear infiltrate intraepithelially and the polymorphonuclear infiltrate in the lamina propria were each graded on a scale of 0 to 3 , and the chronic inflammatory cell infiltrate in the lamina propria was graded on a scale of 0 to 2 . The acute inflammatory score was determined by summing the polymorphonuclear infiltrate scores intraepithelially and in the lamina propria. The chronic inflammatory score was assessed from the severity of the chronic inflammatory cell infiltrate in the lamina propria.

\section{STATISTICAL ANALYSIS}

Statistical analysis was carried out using nonparametric methods. The Mann-Whitney U test and the Wilcoxon matched pairs test were used where appropriate. The Spearman rank correlation test was used to calculate correlation coefficients.

Ethical approval for this study was obtained from the ethical committee at the Southern General Hospital, Glasgow.

\section{Results}

Endoscopy at entry in the $19 \mathrm{H}$ pylori positive patients showed erythematous antral gastritis in 13 patients and erythematous antral gastritis with erythematous duodenitis in six patients. Endoscopy was unremarkable in the seven $H$ pylori negative subjects who had the procedure. Of the 13 patients who received triple therapy, $H$ pylor $i$ was successfully eradicated in 11 , as determined by a negative ${ }^{14} \mathrm{C}$ urea breath test, a negative CLO test, and absence of the bacterium on microscopy of antral biopsy specimens at four weeks after treatment had finished. 
TABLE I Comparison of values between $\mathrm{H}$ pylori positive and $\mathrm{H}$ pylori negative subjects

\begin{tabular}{|c|c|c|c|c|c|c|c|}
\hline & $\begin{array}{l}\text { Plasma ascorbic } \\
\text { acid } \\
(\mu g / m l)\end{array}$ & $\begin{array}{l}\text { Plasma vitamin } C \\
(\mu \mathrm{g} / \mathrm{ml})\end{array}$ & $\begin{array}{l}\text { Gastric juice } \\
\text { ascorbic acid } \\
(\mu g / m l)\end{array}$ & $\begin{array}{l}\text { Gastric juice } \\
\text { vitamin } C \\
(\mu g / m l)\end{array}$ & $\begin{array}{l}\text { Ratio gastric juicel } \\
\text { plasma ascorbic acid }\end{array}$ & $\begin{array}{l}\text { Ratio gastric juicel } \\
\text { plasma vitamin } C\end{array}$ & $\begin{array}{l}\% \text { Vitamin } C \\
\text { as ascorbic acid } \\
\text { in gastric juice }\end{array}$ \\
\hline $\begin{array}{l}\text { H pylori + ve }(\mathrm{n}=19) \\
\text { H pylori }-\mathrm{ve}(\mathrm{n}=10) \\
\text { Statistics }\end{array}$ & $\begin{array}{l}2 \cdot 7(0.42-14 \cdot 7) \\
9 \cdot 3(0.6-24) \\
p=0.2\end{array}$ & $\begin{array}{l}3(0 \cdot 6-19 \cdot 8) \\
7 \cdot 95(0 \cdot 9-23 \cdot 1) \\
p=0 \cdot 2\end{array}$ & $\begin{array}{l}2.8(0-28.8) \\
17.8(5.6-155.4) \\
p<0.0005\end{array}$ & $\begin{array}{l}4 \cdot 4(1-50 \cdot 8) \\
21(8 \cdot 8-150 \cdot 2) \\
p=0 \cdot 0001\end{array}$ & $\begin{array}{l}1 \cdot 16(0.04-6.67) \\
4.87(0.76-21 \cdot 33) \\
\mathrm{p}<0.01\end{array}$ & $\begin{array}{l}1.28(0.21-12.09) \\
4.76(0.72-15.55) \\
\mathrm{p}<0.05\end{array}$ & $\begin{array}{l}55(0-100) \\
92(33 \cdot 7-100) \\
\mathrm{p}<0.05\end{array}$ \\
\hline
\end{tabular}

Results expressed as medians (range).

Eradication therapy was unsuccessful in one patient, and a further patient withdrew from the study.

Plasma ascorbic acid concentrations in $H$ pylori positive patients (range $0 \cdot 4-14 \cdot 7 \mu \mathrm{g} / \mathrm{ml}$ ) did not differ significantly from those in $H$ pylori negative subjects (range $0.6-24 \mu \mathrm{g} / \mathrm{ml})(\mathrm{p}=0.2)$. Similarly, plasma vitamin $\mathrm{C}$ concentrations in $H$ pylori positive patients (range $0 \cdot 6-19 \cdot 8 \mu \mathrm{g} / \mathrm{ml}$ ) did not differ significantly from those in $H$ pylori negative patients (range $0.9-23.1 \mu \mathrm{g} / \mathrm{ml})(\mathrm{p}=$ $0 \cdot 2)$. Gastric juice ascorbic acid concentrations, however, in $H$ pylori positive patients (median $2 \cdot 8$, range $0-28 \cdot 8) \mu \mathrm{g} / \mathrm{ml}$ ) were lower than those in $H$ pylori negative patients (median $17 \cdot 8$ range 5.6-155.4 $\mu \mathrm{g} / \mathrm{ml})(\mathrm{p}<0.0005)($ Table I, Fig 1). Likewise, gastric juice vitamin $\mathrm{C}$ concentrations were lower in $H$ pylori positive patients (median $4 \cdot 4$, range $1-50.8 \mu \mathrm{g} / \mathrm{ml}$ ) compared with $H$ pylori negative patients (median 21 , range 8.8 $150 \cdot 2 \mu \mathrm{g} / \mathrm{ml})(\mathrm{p}=0.0001)$.

The gastric juice:plasma ascorbic acid ratio was lower in $H$ pylori positive patients (median $1 \cdot 16$, range $0 \cdot 02-6 \cdot 67$ ) compared with $H$ pylori negative patients (median 4.87 , range 0.76 $21 \cdot 33)(\mathrm{p}<0.01)$ (Table I, Fig 2). Similarly, the gastric juice:plasma vitamin $\mathrm{C}$ ratio was significantly lower in $H$ pylori positive patients (median $1 \cdot 28$, range $0 \cdot 21-12 \cdot 09$ ) compared with $H$ pylori

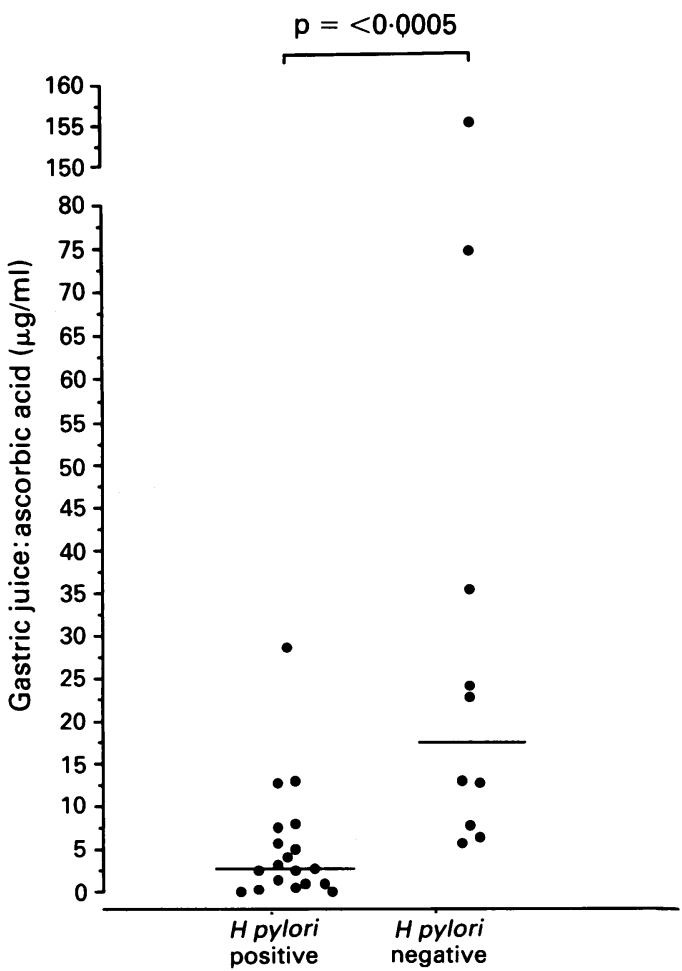

Figure 1: Gastric juice ascorbic acid concentrations ( $\mu \mathrm{g} / \mathrm{ml})$ in $\mathrm{H}$ pylori positive and $\mathrm{H}$ pylori negative subjects. Horizontal lines represent median values. negative patients (median $4 \cdot 76$, range $0 \cdot 72-$ $15.55)(\mathrm{p}<0.05) . H$ pylori positive patients had a significantly lower proportion of their total gastric juice vitamin $\mathrm{C}$ in the active ascorbic acid form (median 55\%, range 0-100\%) compared with $H$ pylori negative patients (median $92 \%$, range $34-100 \%)(\mathrm{p}<0.05)$.

In the $11 H$ pylori positive patients who were successfully eradicated, median gastric juice ascorbic acid concentration rose from $2 \cdot 4$ (range $0-12 \cdot 8 \mu \mathrm{g} / \mathrm{ml})$ to $11 \cdot 2$ (range $0-50 \mu \mathrm{g} / \mathrm{ml})(\mathrm{p}=$ 0.01 ) (Table II, Fig 3), and their gastric juice total vitamin $C$ concentration from 4.4 (range $1-14 \mu \mathrm{g} / \mathrm{ml}$ ) to $11 \cdot 2$ (range $1-43 \mu \mathrm{g} / \mathrm{ml})(\mathrm{p}=$ 0.01 ). There was also a significant rise in their median gastric juice: plasma ascorbic acid ratio, from $1 \cdot 33$ (range $0 \cdot 05-6 \cdot 67$ ) to $2 \cdot 89$ (range $0 \cdot 01$ $166 \cdot 67)(p=0.01)$ (Table II, Fig 4). There was a trend towards an increase in the proportion of gastric juice vitamin $\mathrm{C}$ in the active ascorbic acid form, median values increasing from $64 \%$ (range $0-100 \%$ ) to $82 \%$ (range $0-100 \%$ ), but this was not statistically significant $(p=0 \cdot 1)$. The plasma vitamin $C$ concentrations showed a small but significant rise at four weeks after eradication of $H$ pylori, but there was no change in plasma ascorbic acid concentrations (Table II).

The eight $H$ pylori positive patients reassessed at four months after eradication showed further

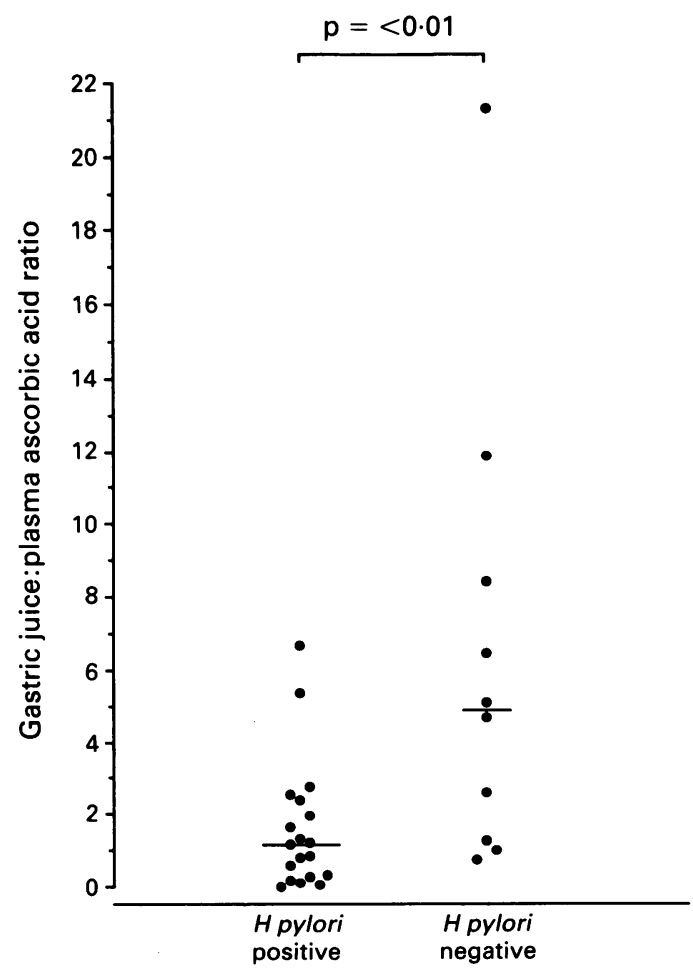

Figure 2: Gastric juice: plasma ascorbic acid ratios in $\mathrm{H}$ pylori positive and $\mathrm{H}$ pylori negative subjects. Horizontal lines represent median values. 
TABLE II Comparison of values before, at four weeks, and four months after eradication of $\mathrm{H}$ pylori

\begin{tabular}{|c|c|c|c|c|c|c|c|}
\hline & $\begin{array}{l}\text { Plasma ascorbic } \\
\text { acid } \\
(\mu g / m l)\end{array}$ & $\begin{array}{l}\text { Plasma vitamin } C \\
(\mu g / m l)\end{array}$ & $\begin{array}{l}\text { Gastric juice } \\
\text { ascorbic acid } \\
(\mu \mathrm{g} / \mathrm{ml})\end{array}$ & $\begin{array}{l}\text { Gastric juice } \\
\text { vitamin } C \\
(\mu g / m l)\end{array}$ & $\begin{array}{l}\text { Ratio gastric juicel } \\
\text { plasma ascorbic acid }\end{array}$ & $\begin{array}{l}\text { Ratio gastric juicel } \\
\text { plasma vitamin } C\end{array}$ & $\begin{array}{l}\% \text { Vitamin } C \\
\text { as ascorbic acid } \\
\text { in gastric juice }\end{array}$ \\
\hline $\begin{array}{l}H \text { pylori }+ \text { ve before } \\
\text { eradication }(n=11) \\
4 \text { Weeks after }\end{array}$ & $2 \cdot 1(0 \cdot 4-10 \cdot 2)$ & $2 \cdot 7(0 \cdot 63-9 \cdot 6)$ & $2 \cdot 4(0-12 \cdot 8)$ & $4-4(1-14)$ & $1 \cdot 33(0.05-6 \cdot 67)$ & $1 \cdot 87(0 \cdot 21-9 \cdot 33)$ & $63 \cdot 6(0-100)$ \\
\hline $\begin{array}{l}\text { eradication }(n=11) \\
\text { Statistics } \\
4 \text { Months after }\end{array}$ & $\begin{array}{l}2 \cdot 1(0-15) \\
\mathrm{p}=0 \cdot 2\end{array}$ & $\begin{array}{l}2.7(1.5-14.7) \\
\mathrm{p}<0.05\end{array}$ & $\begin{array}{l}11 \cdot 2(0-50) \\
p=0 \cdot 01\end{array}$ & $\begin{array}{l}11 \cdot 2(1-43) \\
p=0.01\end{array}$ & $\begin{array}{l}2.89(0.03-166.67) \\
\mathrm{p}<0.05\end{array}$ & $\begin{array}{l}2 \cdot 4(0 \cdot 35-15 \cdot 92) \\
p=0 \cdot 1\end{array}$ & $\begin{array}{l}82 \cdot 1(0-100) \\
\mathrm{p}=0 \cdot 1\end{array}$ \\
\hline $\begin{array}{l}\text { eradication }(n=8) \\
\text { Statistics } \dagger\end{array}$ & $\begin{array}{l}5 \cdot 7(0-14 \cdot 7) \\
p=0 \cdot 6\end{array}$ & $\begin{array}{l}6 \cdot 1(0 \cdot 4-13 \cdot 8) \\
p=0 \cdot 6\end{array}$ & $\begin{array}{l}5 \cdot 4(0-104 \cdot 2) \\
p<0.05\end{array}$ & $\begin{array}{l}6.9(2.2-118) \\
p=0.01\end{array}$ & $\begin{array}{l}4.44(0.01-38) \\
p=0.01\end{array}$ & $\begin{array}{l}5 \cdot 3(0 \cdot 22-10 \cdot 92) \\
p=0.01\end{array}$ & $\begin{array}{l}78 \cdot 4(0-100) \\
\mathrm{p}=0 \cdot 1\end{array}$ \\
\hline
\end{tabular}

Results expressed as medians (range). ${ }^{\star} \mathrm{p}$ values represent comparison of values at entry with those at four weeks after eradication for the 11 patients; $t p$ values represent comparison of values at entry with those at four months after eradication for the eight patients.

increases in median plasma and gastric juice ascorbic acid and vitamin $\mathrm{C}$ concentrations, in the gastric juice:plasma ascorbic acid and vitamin $\mathrm{C}$ ratios, and in the proportion of gastric juice vitamin $C$ in the active ascorbic acid form, compared with median levels at four weeks after eradication. The increase in the gastric juice: plasma vitamin $\mathrm{C}$ ratio, which had failed to reach significance at four weeks, reached significance at four months after eradication (Table II).

The six $H$ pylori positive controls who received no treatment showed no significant change in their plasma and gastric juice ascorbic acid and total vitamin $\mathrm{C}$ concentrations at their two assessments six weeks apart (Table III). Similarly, there was no significant change in their gastric juice:plasma ascorbic acid and vitamin $\mathrm{C}$ ratios, and in the proportion of gastric juice total vitamin $C$ in the active ascorbic acid form.

There was a significant negative correlation between gastric juice ascorbic acid concentrations and the antral acute inflammatory score (correlation coefficient $-0.52, p=0.02$ ), whereas there was no correlation with the antral chronic inflammatory score. Gastric juice vitamin C concentrations showed a weaker though significant correlation with the antral acute inflammatory score (correlation coefficient $-0 \cdot 46, p=0.04)$, but again there was no correlation with the antral chronic inflammatory score. There was no correlation between either the gastric juice ascorbic acid or vitamin $C$ concentrations and the gastric corpus inflammatory scores. In addition, there was no correlation between the 20 minute reading of the ${ }^{14} \mathrm{C}$ urea breath test and gastric juice ascorbic acid and vitamin $\mathrm{C}$ concentrations.

\section{Discussion}

Our findings confirm that $H$ pylori gastritis is associated with low gastric juice ascorbic acid and total vitamin $\mathrm{C}$ concentrations, median concentrations of the first being six times lower, and of the second around five times lower than in $H$ pylori negative subjects. The reason for the comparatively lower gastric juice ascorbic acid concentrations is that $H$ pylori positive patients have a smaller proportion of the gastric juice total vitamin $\mathrm{C}$ in the ascorbic acid form, with larger amounts in the oxidised dehydroascorbic acid form, which does not confer protection against $N$-nitrosation. Our study has shown that these

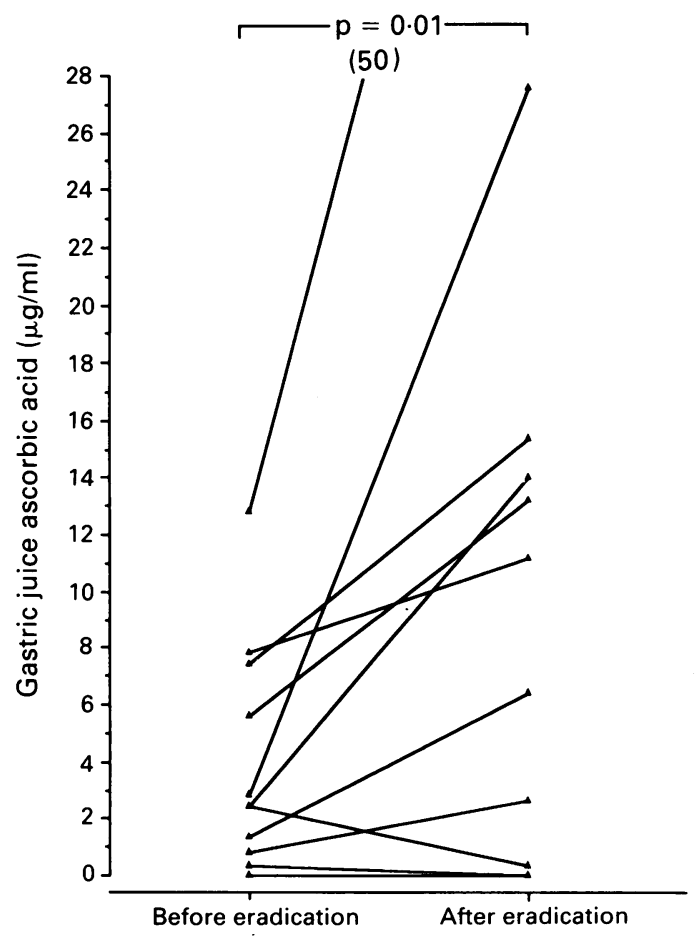

Figure 3: Gastric juice ascorbic acid concentrations ( $\mu \mathrm{g} / \mathrm{ml}$ ) before and after eradication of $\mathrm{H}$ pylori.

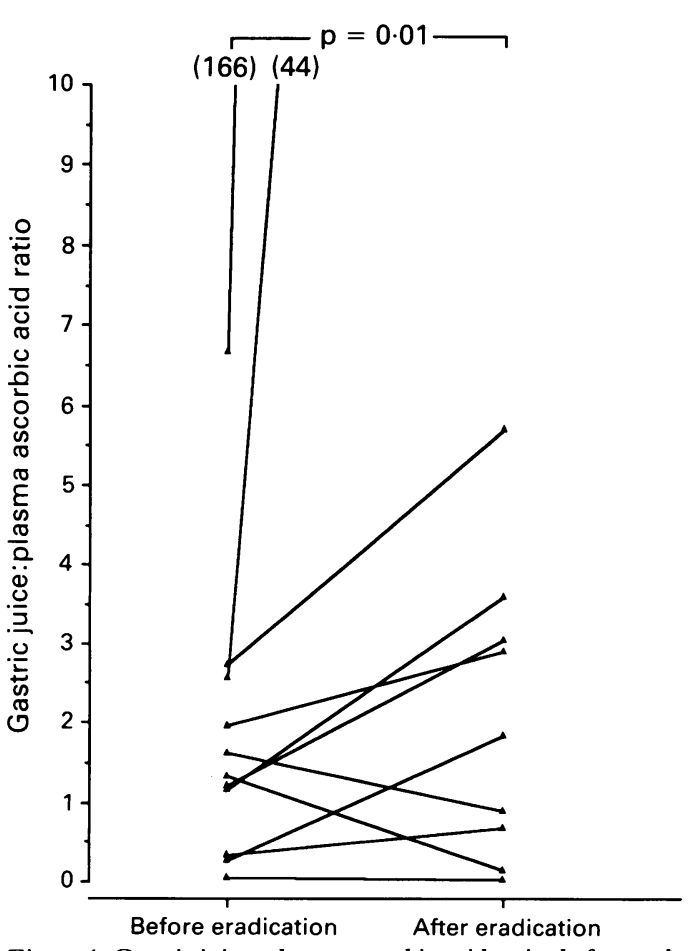

Figure 4: Gastric juice: plasma ascorbic acid ratios before and after eradication of $\mathbf{H}$ pylori. 
TABLE III H pylori positive controls: comparison of values on two visits six weeks apart

\begin{tabular}{|c|c|c|c|c|c|c|c|}
\hline & $\begin{array}{l}\text { Plasma ascorbic } \\
\text { acid } \\
(\mu g / m l)\end{array}$ & $\begin{array}{l}\text { Plasma vitamin } C \\
(\mu g / m l)\end{array}$ & $\begin{array}{l}\text { Gastric juice } \\
\text { ascorbic acid } \\
(\mu g / m l)\end{array}$ & $\begin{array}{l}\text { Gastric juice } \\
\text { vitamin } C \\
(\mu g / m l)\end{array}$ & $\begin{array}{l}\text { Ratio gastric juicel } \\
\text { plasma ascorbic acid }\end{array}$ & $\begin{array}{l}\text { Ratio gastric juicel } \\
\text { plasma vitamin C }\end{array}$ & $\begin{array}{l}\% \text { Vitamin } C \\
\text { as ascorbic acid } \\
\text { in gastric juice }\end{array}$ \\
\hline \multirow{2}{*}{$\begin{array}{l}H \text { pylori + ve controls } \\
\text { (visit I) }(\mathrm{n}=6) \\
H \text { pylori }+ \text { ve controls } \\
\text { (visit II) }(\mathrm{n}=6) \\
\text { Statistics }\end{array}$} & $4 \cdot 2(2 \cdot 1-6 \cdot 6)$ & $4 \cdot 3(2 \cdot 4-6 \cdot 6)$ & $3 \cdot 6(0-28)$ & $4 \cdot 7(1 \cdot 6-50 \cdot 8)$ & $0.71(0.02-5 \cdot 33)$ & $1 \cdot 24(0 \cdot 2-12 \cdot 09)$ & $52 \cdot 6(0-100)$ \\
\hline & $\begin{array}{l}2 \cdot 2(0 \cdot 3-8 \cdot 4) \\
\mathrm{p}=\mathrm{NS}\end{array}$ & $\begin{array}{l}3 \cdot 4(0 \cdot 3-8 \cdot 4) \\
\mathrm{p}=\mathrm{NS}\end{array}$ & $\begin{array}{l}4 \cdot 3(0 \cdot 2-18) \\
\mathrm{p}=\mathrm{NS}\end{array}$ & $\begin{array}{l}7 \cdot 2(2-25 \cdot 2) \\
\mathrm{p}=\mathrm{NS}\end{array}$ & $\begin{array}{l}1 \cdot 13(0 \cdot 45-12) \\
\mathrm{p}=\mathrm{NS}\end{array}$ & $\begin{array}{l}1 \cdot 95(0 \cdot 8-16 \cdot 8) \\
p=N S\end{array}$ & $\begin{array}{l}53 \cdot 5(10-71 \cdot 4) \\
\mathrm{p}=\mathrm{NS}\end{array}$ \\
\hline
\end{tabular}

Results expressed as medians (range). NS=not significant.

abnormalities are secondary to $H$ pylori infection as they resolve after its eradication.

The physiological mechanism by which ascorbic acid is normally concentrated in gastric juice is unclear. The $\mathrm{pK}_{\mathrm{a}}$ of ascorbic acid is $4 \cdot 1$, and thus plasma ascorbic acid is largely in the ionised state. This rules out the mechanism of non-ionic diffusion followed by ionic trapping and concentration in the acidic gastric juice. It therefore seems probable that the gastric mucosa actively secretes ascorbic acid into gastric juice. Studies have shown that ascorbic acid concentrations are highest in the antral mucosa, ${ }^{1}$ suggesting that this is the region of the stomach participating in the secretion of ascorbic acid.

The mechanism whereby $H$ pylori infection lowers gastric juice ascorbic acid concentrations is also unclear. Cytopathic toxins released by the bacterium may impair the mucosal ascorbic acid secretory mechanisms. An alternative explanation for the low gastric juice ascorbic acid concentrations associated with $H$ pylori infection is that it is a result of the antral gastritis induced by the infection. Consistent with this is our finding of a significant negative correlation between gastric juice ascorbic acid concentration and the acute inflammatory score in the antral mucosa. A product of the polymorphonuclear cells could impair the ascorbic acid secretory mechanism itself, or increase the consumption/ degradation of ascorbic acid in the antral mucosa, resulting in lower amounts being available for secretion into the gastric juice. $H$ pylor has been shown to potentiate the polymorphonuclear leucocyte oxidative burst, ${ }^{21}$ which is accompanied by a considerable production of reactive oxygen metabolites. Plasma ascorbic acid within the microcirculation of the gastric mucosa may be consumed in the course of scavenging these reactive oxygen metabolites. Ascorbic acid in gastric juice may be similarly degraded by the gastritic process, thus further lowering ascorbic acid concentrations, and resulting in the comparatively higher concentrations of dehydroascorbic acid seen in the gastric juice of $H$ pylori positive patients.

Plasma total vitamin $C$ concentrations showed a small but significant increase after eradication of $H$ pylori. This may be explained by decreased tissue degradation of vitamin $\mathrm{C}$ after resolution of gastric inflammation. It is difficult, however, to absolutely rule out improved nutrition after eradication of $H$ pylori, as patient's eating habits may change after resolution of dyspepsia. Although systemic inflammatory diseases such as rheumatoid arthritis are associated with low plasma ascorbic acid concentrations, ${ }^{22}$ localised inflammation in the stomach will probably not influence plasma ascorbic acid concentrations to the same extent. Thus, in $H$ pylori positive patients, dietary vitamin $C$ intake would remain the main determinant of plasma ascorbic acid concentrations, whereas the intensity of the antral acute inflammatory infiltrate may be the main determinant of gastric juice ascorbic acid concentrations.

The depletion of gastric juice ascorbic acid caused by $H$ pylori infection may be important in the association between infection and subsequent development of gastric carcinoma. ${ }^{3-15}$ Epidemiological studies have shown that diets rich in vitamin $\mathrm{C}$ reduce the risk of gastric carcinoma. $^{\text {s-9 }}$ The protective effect may be because of ascorbic acid in gastric juice inhibiting the formation of carcinogenic $N$-nitroso compounds. Intragastric bacteria in the hypochlorhydric stomach convert dietary nitrates to nitrites, which in turn combine with dietary amines and amides to form carcinogenic $N$-nitroso compounds. Ascorbic acid scavenges nitrites, thus preventing formation of $N$-nitroso compounds. ${ }^{23-27}$ The ability of ascorbic acid to scavenge reactive oxygen metabolites ${ }^{28}$ may be a further mechanism whereby it protects against gastric carcinoma. Reactive oxygen metabolites may damage DNA, leading to strand scission, fragmentation, and destruction of bases and deoxyribose sugars, thus predisposing to chromosomal abberations, mutations, and possibly to eventual neoplastic transformation. ${ }^{29-31}$

The ability of ascorbic acid to scavenge reactive oxygen metabolites may also protect against mucosal ulceration. Reactive oxygen metabolites cause lipid peroxidation and adversely affect the basement membrane, epithelial function, and the mucus layer. ${ }^{3233}$ Duodenal ulceration produced in rats by stimulating excess acid secretion by pentagastrin or carbachol can be prevented by administration of the free radical scavengers allopurinol and dimethyl sulphoxide. ${ }^{3+}$ Together with other synergistic factors, reactive oxygen metabolites may also participate in peptic ulcer disease in humans. Peptic ulceration is associated with high circulating concentrations of markers of free radical activity and reduced plasma antioxidant concentrations. ${ }^{35}$ In addition, allopurinol has been reported to be more effective than cimetidine in preventing duodenal ulcer relapse ${ }^{36}$ and given concurrently with $\mathrm{H}_{2}$ receptor blockers, may accelerate the healing of intractable duodenal ulcers. ${ }^{37}$

In conclusion, these studies show that $H$ pylori causes considerable but reversible lowering of gastric juice ascorbic acid concentrations. This may be an important factor in the link between $H$ pylori infection and both gastric carcinoma and peptic ulceration. 
We are grateful to $\mathrm{Dr} W \mathrm{~S}$. Watson for his help with the ${ }^{{ }^{4} \mathrm{C}}$ urea breath tests. We also gratefully acknowledge the expert technical assistance of Mr J Hearns and Mrs M McDade.

1 Rathbone B, Johnson A, Wyatt J, et al. Ascorbic acid: a factor concentrated in human gastric juice. Clin Sci 1989; 76: 237-41

2 Sobala G, Schorah C, Sanderson M, et al. Ascorbic acid in the human stomach. Gastroenterology 1989; 97: 357-63.

3 Sobala G, Pignatelli B, Schorah C, et al. Levels of nitrite, nitrate, N-nitroso compounds, ascorbic acid and total bile acids in gastric juice of patients with and without preacids in gastric juice of patients with and without pre-
cancerous conditions of the stomach. Carcinogenesis 1991; cancerous

4 Schorah C, Sobala G, Sanderson M, et al. Gastric juice ascorbic acid: effects of disease and implications for gastric carcinogenesis. Am F Clin Nutr 1991; 53: 287-93S

5 Stahelin H, Rosel F, Buess E, Brubacher G. Dietary risk factors for cancer in the Basel Study. Bibl Nutr Dieta 1986; 37: 144-53.

6 Jedrychowski W, Wahrendorf J, Popiela T, Rachtan J. A casecontrol study of dietary factors and stomach cancer risk in Poland. Int f Cancer 1986; 37: 837-42.

7 Bjelke E. Epidemiological studies of cancer of the stomach, colon and rectum; with a special emphasis on the role of diet. Scand $\mathcal{F}$ Gastroenterol 1979; 9 (suppl): 231-5.

8 Cuello C, Correa P, Haenszel W, et al. Gastric cancer in Columbia. Cancer risk and suspect environmental agents. Columbia. Cancer risk and suspect

9 Risch H, Jain M, Choi N, et al. Dietary factors and the incidence of cancer of the stomach. Am $\mathcal{F}$ Epidemiol 1985; 122: 947-59.

10 Coghlan J, Gilligan D, Humphries $\mathrm{H}$, et al. Campylobacter pylori and recurrence of duodenal ulcers - a 12 month follow up study. Lancet 1987; ii: 1109-11.

11 Rauws E, Langenberg W, Houthoff $\mathrm{H}$, et al. Campylobacter pyloridis associated chronic active antral gastritis: a prospective study of its prevalence and the effects of antibacterial and antiulcer treatment. Gastroenterology 1988; 94 : 33-40.

12 Marshall B, McGechie D, Rogers P, et al. Pyloric Campylobacter infection and gastroduodenal disease. Med $\mathcal{F}$ Aust 1985; 142: 439-44.

13 Parsonnet, Friedman G, Vandersteen D, et al. Helicobacter pylori infection and the risk of gastric carcinoma. $N$ Engl f Med 1991; 325: 1127-31.

14 Nomura A, Stemmermann G, Chyou P, et al. Helicobacter pylori infection and gastric carcinoma among Japanese Americans in Hawaii. N Engl f Med 1991; 325: 1132-6.

15 Forman D, Newell D, Fullerton F, et al. Association between infection with Helicobacter pylori and risk of gastric cancer: evidence from a prospective investigation. $B M \mathcal{F} 1991 ; 302$ : 1302-5.

16 Sobala GM, Crabtree JE, Dixon MF, Schorah CJ, Taylor JD, Rathbone BJ, et al. Acute Helicobacter pylori infection: clinical features, local and systemic immune response, clinical features, local and systemic immune response, gastric mucosal histology, and gastric

17 Goldie J, Jalali S, Van Zanten S, Stowe C, Hunt RH. Ascorbic acid inhibits the growth and urease activity of Campylobacter pylori. Gut 1989; 30: A1484.
18 Armstrong $\mathrm{F}$, Sohel $\mathrm{R}$, Slater $\mathrm{T}$. Free radicals in molecular biology, ageing and disease. New York: Raven Press, 1984.

19 Bridges A, Fisher T, Scott N, et al. Circadian variation of white blood cell function and endothelial cell proliferation in normal volunteers. BrF Haematol 1990; 76 (suppl 1): 37.

20 Nujumi AE, Rowe P, Dahill S, Dorrian CA, Neithercut WD, McColl KEL. Role of ammonia in the pathogenesis of the gastritis, hypergastrinaemia, and hyperpepsinogenaemia I $1612-6$.

21 Mooney C, Keenan J, Munster D, Wilson I, Allardyce R, Bagshaw $\mathrm{P}$, et al. Neutrophil activation by Helicobacter pylori. Gut 1991; 32: 853-7.

22 Lunec J, Blake D. The determination of dehydroascorbic acid and ascorbic acid in the serum and synovial fluid of patients and ascorbic acid in the serum and synovial fluid of patients with r.

23 Licht $\mathbb{W}$, Tannenbaum S, Deen W. Use of ascorbic acid to inhibit nitrosation: kinetic and mass transfer conditions for an in vitro system. Carcinogenesis 1988; 9: 365-72.

24 Mirvish S, Wallcave L, Eagen M, Shubik P. Ascorbate nitrate reaction: possible means of blocking the formation of carcinogenic N-nitroso compounds. Science 1972; 177: 65-8.

25 Wagner D, Shuker D, Bilmazes C, et al. Effect of vitamins C and $E$ on endogenous synthesis of $\mathrm{N}$-nitrosoamino acids in humans: precursor product studies with [15N]nitrate. Cancer Res 1985; 45: 5619-22.

26 Oshima H, Bartsh H. Quantitative estimation of endogenous nitrosation in humans by monitoring $\mathbf{N}$-nitrosoproline excreted in the urine. Cancer Res $1981 ; 41$; 3658-62.

27 Reed P, Johnstone B, Walters C, Hill M. Effect of ascorbic acid on the intragastric environment in patients at increased risk of developing gastric cancer. IARC 1991; 105: 139-42.

28 Niki E. Action of ascorbic acid as a scavenger of active and stable oxygen radicals. Am F Clin Nutr 1991; 54: 1119-24S.

29 Aruoma O, Halliwell B, Dizdaroglu M. Iron ion-dependent modification of bases in DNA by the superoxide radical generating system hypoxanthine/xanthine oxidase. $\mathcal{f} \mathrm{Biol}$ Chem 1989; 264: 13024-8.

30 Clemens $M$. Free radicals in chemical carcinogenesis. Klin Wochenschr 1991; 69: 1123-34.

31 Santamaria L, Bianchi-Santamaria A. Free radicals as carcinogens and their quenchers as carcinogens. Med Oncol Tumor Pharmacother 1991; 8: 121-40.

32 Maestro RD, Thaw $\mathrm{H}$, Bjork J, et al. Free radicals as mediators of tissue injury. Acta Physiol Scand 1980; 492 (suppl): 43-57.

33 Grisham M, Von Ritter C, BF S, et al. Interaction between oxygen radicals and gastric mucin. Am $\mathcal{F}$ Physiol 1987; 253: G93-6.

34 Salim A. Role of oxygen derived free radicals in mechanism of acute and chronic duodenal ulceration in the rat. $\mathrm{Dig} \mathrm{Dis} S \mathrm{Si}$ 1990; 35: 73-9.

35 Jankowski J, Bridges A, Scott $\mathbf{N}$. Circulating free radical markers and peptic ulcer disease. Eurf Gastroenterol Hepatol 1991; 3: 823-8.

36 Salim A. Oxygen derived free radicals and the prevention of duodenal ulcer relapse: a new approach. Am f Med Sci 1990; 300: $1-6$.

37 Salim A. A possible new approach to the problem of refractory peptic ulceration. A role for free radical scavengers. Scott Med F 1991; 36: 19-20. 